\title{
Availability of Adequately Iodized Dietary Salt and Associated Factors in a Town of Southeast Ethiopia: A Community-Based Cross-Sectional Survey
}

\author{
Gadisa Fitala Obssie, ${ }^{1}$ Kassahun Ketema, ${ }^{2}$ and Yohannes Tekalegn ${ }^{2}{ }^{2}$ \\ ${ }^{1}$ Gobe Health Center, West Arsi Health Department, Oromia Regional Health Bureau, Kore Town, Ethiopia \\ ${ }^{2}$ Department of Public Health, School of Health Science, Goba Referral Hospital, Madda Walabu University, Bale Robe, Ethiopia \\ Correspondence should be addressed to Yohannes Tekalegn; yohannesefa@gmail.com
}

Received 29 May 2020; Revised 12 November 2020; Accepted 25 November 2020; Published 4 December 2020

Academic Editor: Frederick Ato Armah

Copyright (C) 2020 Gadisa Fitala Obssie et al. This is an open access article distributed under the Creative Commons Attribution License, which permits unrestricted use, distribution, and reproduction in any medium, provided the original work is properly cited.

\begin{abstract}
Background. Iodine deficiency is the world's major cause of preventable intellectual impairment, and nearly 2 billion people are at risk of iodine deficiency worldwide. Prevention and control of iodine deficiency disorders primarily aim at ensuring the intake of adequate iodine to maintain normal thyroid function. In our study area, studies regarding the coverage of adequately iodized salt at household level are meager. Hence, this study aimed to assess the magnitude of adequately iodized dietary salt at a household level in Kore Town, Southeast Ethiopia. Methods. A community-based cross-sectional study was conducted in the Kore town from August 1 to 30,2019. A total of 394 households were selected for this study using a simple random sampling technique. The level of salt iodine content was determined using the rapid field test kit. Then, iodine contents of dietary salt were reported as $<15$ parts per million and $\geq 15$ parts per million. Data regarding sociodemographic factors, knowledge of respondents about iodized salt, and iodized salt handling practices were collected through a face-to-face interview. The binary logistic regression model was used to assess the association between independent factors and the outcome variable. Statistical significance was declared at $p<0.05$. Result. Out of all the households, 223 (56.6\%) had adequately iodized salt. Not exposing iodized salt to sunlight $(\mathrm{AOR}=2.35,95 \%$ CI: $1.1,5.2)$, storing the salt at a dry or cold place $[(\mathrm{AOR}=4.77,95 \% \mathrm{CI}: 1.39,16.45)$ and $(\mathrm{AOR}=8.23,95 \% \mathrm{CI}: 1.44,47.19)$, respectively], and having good knowledge about iodized salt ( $\mathrm{AOR}=1.88,95 \% \mathrm{CI}: 1.18,3.01)$ were significantly associated with the presence of adequately iodized salt at the household level. Conclusion. Availability of adequately iodized salt in the study area was far below the World Health Organization recommendation. Information regarding the importance and proper handling of iodized dietary salt should be communicated to the householders.
\end{abstract}

\section{Background}

Iodine is an essential element needed for life. It plays a vital role in the production of thyroid hormone in humans as well as in all vertebrates. Iodine deficiency can lead to serious health problems, including goiter, mental retardation, and cretinisms [1-4]. Iodine deficiency is a public health problem throughout the world. Globally, about 2 billion people are at risk of iodine deficiency $[5,6]$. In developing countries, 38 million newborn babies per year are at risk of the devastating consequences of iodine deficiency [7]. In Ethiopia, $62 \%$ of the people are at risk of iodine deficiency [8].
The World Health Organization recommends a daily iodine intake of 50 micrograms for infants, 90 micrograms for preschool children, 120 micrograms for school children, 150 micrograms for adults, and 250 micrograms for pregnant and lactating mothers to prevent iodine deficiency disorders $[9,10]$. Despite this, one-third of the world population lives in the area with some iodine deficiency [11].

Prevention and control of iodine deficiency disorders primarily aim at ensuring adequate intake of dietary iodine. Increased dietary iodine intake can be implemented through food fortification with iodine. Salt is the most commonly used vehicle since it is inexpensive and widely available. The 
World Health Organization recommends eliminating iodine deficiency disorders through universal salt iodization [1].

Coverage of iodized salt shows a gradual improvement in Ethiopia as it was $28.4 \%$ in 2000 [12], $54.3 \%$ in 2005 [13], $15.4 \%$ in 2011 [14], $88.8 \%$ in 2014 [15], and $89 \%$ in 2016 [16]. However, disparities exist in terms of adequacy of the iodine level in dietary salt and its utilization level within and between different regions of the country [15]. In Ethiopia, household surveys of salt iodine levels were conducted at a different time and reported a low level of adequately iodized salt $[15,17-21]$.

To eliminate iodine deficiency disorders, the World Health Organization recommends that at least $90 \%$ of households should be able to access adequately iodized salt [1]. Assessing the proportion of households with access to adequately iodized dietary salt is very essential in tracking progress towards universal salt iodization. In this aspect, there are no studies conducted in our study area that assess the level of adequately iodized salt at household level. Therefore, this study aimed to assess the magnitude and factors associated with availability of adequately iodized dietary salt at household level in Kore Town, Southeast Ethiopia.

\section{Materials and Methods}

2.1. Study Design and Setup. A community-based crosssectional study was conducted in the Kore town from August 01 to 30,2019 . The town is located at 49 kilometers in the northeastern direction of Shashemene town, capital of West Arsi zone, Southeast Ethiopia. The town has a total of 1033 households and about 4956 total population. The major crops produced in the woreda include wheat, barley, bean, pea, potato, inset, cabbage, onion, and maize.

\subsection{Sample Size Determination and Sampling Procedure.} The sample size of the study was calculated using Epi Info version 7 software. The following assumptions were used: the proportion of households with adequately iodized salt was $63 \%$ [22], 95\% confidence level, and a 5\% margin of error. The final sample size was 394 households, after adding a $10 \%$ contingency for possible nonresponse. The samples of households were selected randomly from the list of all households in the town using a simple random sampling technique. The sampling frames of the households were obtained from the town's health department.

2.3. Data Collection Tools, Procedure, and Quality Assurance. A structured, interviewer-administered questionnaire was used to collect the data. The questionnaire was first prepared in English and translated into the local language (Afan Oromo) and finally backtranslated to English to ensure consistency. The questionnaire contains queries regarding sociodemographic variables, knowledge of iodized salt, and utilization of iodized salt. The questionnaires were pretested on five percent of the sample before the actual data collection. Eight data collectors and two supervisors were recruited for the study. The data collectors were health professionals with a bachelor's degree, and the supervisors were public health professionals with a master's degree. Two days of training were given for data collectors and supervisors regarding data collection techniques. Completeness of questionnaires was checked daily throughout the data collection period.

2.4. Determination of the Iodine Content of the Salt. A tablespoon full of salt was collected from each sampled household, and the rapid test kit (RTK) was used to determine the level of salt iodine content. The small cup in the kit was filled with salt, and the cup surface was made flat. Two drops of the test solution from a white ampoule were added to the surface of the salt by piercing the white ampoule with a pin and gently squeezing the ampoule. The iodine content in the salt was determined within one minute by comparing the color change on the salt against the standard color chart. If no color appears after 1 minute, 5 drops of the recheck solution from the red ampoule was added to a fresh salt sample and followed by 2 drops of the test solution on the same salt sample. Then, a comparison was done with the standard color chart [1]. Based on the reading from the standard color chart values, the samples were categorized into $<15$ parts per million (inadequately iodized salt) or $\geq 15$ parts per million (adequately iodized salt) [1].

\subsection{Dependent Variable}

2.5.1. Availability of Adequately Iodized Salt in Household. As described above, availability of adequately iodized salt was dichotomized into two categories either as adequately iodized or inadequately iodized.

2.5.2. Independent Variables. Independent variables include variables related with sociodemographic characteristics of householders, iodized salt handling practices, and knowledge of householders about iodized salt.

2.6. Data Processing and Analysis. The data were entered using EpiData version 3.1 and analyzed using SPSS version 20. Summary statistics like frequency, percent, mean, and standard deviation were used to describe data. Univariate and multivariate binary logistic regression analysis was used to assess the association between the outcome variable and independent variables. Multi-colinearity was checked for all independent variables using the variation inflation factor (VIF). Variables with $p$ value $=0.05$ in the univariate analysis were entered into a multivariate binary logistic regression mode. Hosmer-Lemeshow goodness of fit was used to check the fitness of the final model. Adjusted odds ratio with $95 \%$ confidence interval was used to report the strength of associations. $p$ value $<0.05$ in the multivariate 
TABLE 1: Sociodemographic characteristics of respondents in Kore Town, Southeast Ethiopia, 2019.

\begin{tabular}{|c|c|c|c|c|}
\hline \multirow[t]{2}{*}{ Variables } & \multicolumn{2}{|c|}{$\begin{array}{c}\text { Availability of adequately iodized salt in } \\
\text { the household }\end{array}$} & \multirow[t]{2}{*}{ Cramer's V } & \multirow[t]{2}{*}{$\mathrm{Chi}^{2} p$ value } \\
\hline & Adequate, $n(\%)$ & Inadequate, $n(\%)$ & & \\
\hline \multicolumn{5}{|l|}{ Age } \\
\hline $15-24$ years & $85(48.0)$ & $92(52.0)$ & \multirow{4}{*}{0.1} & \multirow{4}{*}{0.001} \\
\hline $25-34$ years & $86(58.9)$ & $60(41.1))$ & & \\
\hline $35-44$ years & $40(78.4)$ & $11(21.6)$ & & \\
\hline$\geq 45$ years & $12(60.0)$ & $8(40.0)$ & & \\
\hline \multicolumn{5}{|l|}{ Marital status } \\
\hline Married & $155(57.6)$ & $114(42.4)$ & \multirow{3}{*}{0.03} & \multirow{3}{*}{0.8} \\
\hline Single & $63(54.8)$ & $52(45.2)$ & & \\
\hline Divorced/widowed & $5(50.0)$ & $5(50.0)$ & & \\
\hline \multicolumn{5}{|l|}{ Ethnicity } \\
\hline Oromo & $185(54.4)$ & $155(45.6)$ & \multirow{3}{*}{0.1} & \multirow{3}{*}{0.03} \\
\hline Amhara & $29(76.3)$ & $9(23.7)$ & & \\
\hline Others $^{\mathrm{a}}$ & $9(56.2)$ & $7(43.8)$ & & \\
\hline \multicolumn{5}{|l|}{ Religion } \\
\hline Muslim & $157(51.0)$ & $151(49.0)$ & \multirow{3}{*}{0.2} & \multirow{3}{*}{$<0.001$} \\
\hline Orthodox & $42(76.4)$ & $13(23.6)$ & & \\
\hline Protestant & $24(77.4)$ & $7(22.6)$ & & \\
\hline \multicolumn{5}{|c|}{ Family size of households } \\
\hline $2-6$ persons & $157(57.5)$ & $116(42.5)$ & \multirow{3}{*}{0.07} & \multirow{3}{*}{0.4} \\
\hline $7-11$ persons & $62(56.4)$ & $48(43.6)$ & & \\
\hline $12-16$ persons & $4(36.4)$ & $7(63.4)$ & & \\
\hline \multicolumn{5}{|c|}{ Average monthly income of the household head in $E T B^{\mathrm{b}}$} \\
\hline$<1001^{\circ}$ & $108(50.5)$ & $106(49.5)$ & \multirow{5}{*}{0.2} & \multirow{5}{*}{0.006} \\
\hline $1001-2000$ & $40(52.6)$ & $36(47.4)$ & & \\
\hline $2001-3000$ & $34(69.4)$ & $15(30.6)$ & & \\
\hline $3001-4000$ & $18(72.0)$ & $7(28.0)$ & & \\
\hline$\geq 4001$ & $23(76.7)$ & $7(23.3)$ & & \\
\hline
\end{tabular}

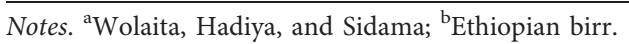

binary logistic analysis was used to declare statistical significance.

2.7. Ethical Considerations. Ethical clearance was obtained from the Ethical Review Committee of Madda Walabu University, Goba Referral Hospital, with the letter reference number 01/2/10256. Formal cooperation letter was written from the Madda Walabu University Goba Referral Hospital Academic and Research directorate to Kore woreda administration. After receiving permission from the respective woreda and town authorities, verbal informed consent was obtained from each head of the households before the interview and salt testing process. Health information about the use of iodized salt and handling practices was given to each respondent after data collection.

\subsection{Operational Definitions}

Adequately Iodized Salt. If the householders' salt samples had $\geq 15$ ppm of iodized salt after testing with the rapid test kit.

Knowledge about Iodized Salt. A series of ten questions related to uses of iodized salt, sources of iodized salt, and knowledge of iodine deficiency-related disorders were asked.
Score of " 1 " was given for correct answers and "0" for incorrect answers. Study participants who scored at least $50 \%$ on the knowledge questions were categorized as having good knowledge, and others were categorized as having poor knowledge.

\section{Results}

3.1. Sociodemographic Characteristics of Respondents. A total of 394 households were included in this study with a response rate of $100 \%$. The mean age of respondents was 27 years with a standard deviation of 8.7 years. All of the household members who participated in food preparation were females (Table 1).

3.2. Knowledge of Respondents about Iodized Salt and Its Proper Handling. Out of all households, 214 (54.3\%) of the households use unpacked dietary salt. Regarding the type of the container, 200 (50.8\%) of the participants use a closed plastic container and $341(86.5 \%)$ store dietary salt at a dry place. Concerning sunlight exposure, 358 (91.1\%) of the study respondents did not expose their dietary salt to the sunlight. Out of all respondents, 174 (44.2\%) add dietary salt to the food from the beginning of the cooking process (Table 2). 
TAвLE 2: Dietary salt handling practice of householders in Kore Town, Southeast Ethiopia, 2019.

\begin{tabular}{|c|c|c|c|c|}
\hline \multirow[t]{2}{*}{ Variables } & \multicolumn{2}{|c|}{$\begin{array}{c}\text { Availability of adequately iodized salt in the } \\
\text { household }\end{array}$} & \multirow[t]{2}{*}{ Cramer's V } & \multirow[t]{2}{*}{$\mathrm{Chi}^{2} p$ value } \\
\hline & Adequate, $n(\%)$ & Inadequate, $n(\%)$ & & \\
\hline $\begin{array}{l}\text { Type of dietary } \\
\text { salt } \\
\text { Unpacked }^{\mathrm{a}} \\
\text { Packed }\end{array}$ & $\begin{array}{l}100(46.7) \\
123(68.3)\end{array}$ & $\begin{array}{c}114(53.3) \\
57(31.7)\end{array}$ & 0.2 & $<0.001$ \\
\hline $\begin{array}{l}\text { Type of } \\
\text { container } \\
\text { Plastic package } \\
\text { Closed plastic } \\
\text { cup } \\
\text { Open plastic cup }\end{array}$ & $\begin{array}{l}68(70.1) \\
110(55.0) \\
45(46.4) \\
\end{array}$ & $\begin{array}{l}29(29.9) \\
90(45.0) \\
52(53.6) \\
\end{array}$ & 0.2 & 0.003 \\
\hline $\begin{array}{l}\text { Storage place } \\
\text { Dry place } \\
\text { Cold place } \\
\text { Near cooking } \\
\text { fire } \\
\text { Moist place }\end{array}$ & $\begin{array}{c}199(58.4) \\
9(69.2) \\
11(52.4) \\
4(21.1) \\
\end{array}$ & $\begin{array}{c}142(41.6) \\
4(30.8) \\
10(47.6) \\
15(78.9)\end{array}$ & 0.2 & 0.01 \\
\hline $\begin{array}{l}\text { Exposing salt to } \\
\text { sunlight } \\
\text { Yes } \\
\text { No }\end{array}$ & $\begin{array}{c}14(38.9) \\
209(58.4)\end{array}$ & $\begin{array}{c}22(61.1) \\
149(41.6)\end{array}$ & 0.1 & 0.02 \\
\hline $\begin{array}{l}\text { Washing iodized } \\
\text { salt } \\
\text { Yes } \\
\text { No } \\
\end{array}$ & $\begin{array}{c}16(45.7) \\
207(57.7)\end{array}$ & $\begin{array}{c}19(54.3) \\
152(42.3) \\
\end{array}$ & 0.1 & 0.1 \\
\hline $\begin{array}{l}\text { Types of the } \\
\text { market to buy } \\
\text { dietary salt } \\
\text { Open market } \\
\text { Supermarket }\end{array}$ & $\begin{array}{l}131(50.6) \\
95(70.4)\end{array}$ & $\begin{array}{c}128(49.4) \\
40(29.6)\end{array}$ & 0.2 & $<0.001$ \\
\hline $\begin{array}{l}\text { Duration of } \\
\text { storing dietary } \\
\text { salt } \\
<2 \text { months } \\
\geq 2 \text { months } \\
\end{array}$ & $\begin{array}{c}214(56.3) \\
9(64.3) \\
\end{array}$ & $\begin{array}{c}166(43.7) \\
5(35.7) \\
\end{array}$ & 0.1 & 0.07 \\
\hline $\begin{array}{l}\text { Time to add } \\
\text { dietary salt to the } \\
\text { cooked food } \\
\text { From the } \\
\text { beginning of the } \\
\text { cooking process } \\
\text { In the middle of } \\
\text { the cooking } \\
\text { process } \\
\text { At the end of the } \\
\text { cooking process }\end{array}$ & $74(83.1)$ & $\begin{array}{l}92(52.9) \\
64(48.9)\end{array}$ & 0.3 & $<0.001$ \\
\hline
\end{tabular}

3.3. The Magnitude of Households with Adequately Iodized Salt. Out of all households, $223(56.6 \%)$ had adequately iodized salt and the remaining 171 (43.4\%) had inadequately iodized salt.

3.4. Factors Associated with the Availability of Adequately Iodized Dietary Salt. Multiple binary logistic regression analysis found that not exposing iodized salt to sunlight $(\mathrm{AOR}=2.35,95 \% \mathrm{CI}: 1.1,5.2)$, storing dietary salt at a dry and cold place $[(\mathrm{AOR}=4.77,95 \% \mathrm{CI}: 1.39,16.45)$ and
$(\mathrm{AOR}=8.23,95 \% \mathrm{CI}: 1.44,47.19)$, and having good knowledge about iodized salt $(\mathrm{AOR}=1.88,95 \% \mathrm{CI}: 1.18$, 3.01) were significantly associated with the presence of adequately iodized salt at household level (Table 3).

\section{Discussion}

This study aimed to assess the magnitude of households with adequately iodized dietary salt in the town of Kore, Southeast 
TABLE 3: Factors associated with the availability of adequately iodized dietary salt at household level in Kore Town, Southeast Ethiopia, 2019.

\begin{tabular}{|c|c|c|c|}
\hline \multirow[t]{2}{*}{ Variables } & \multicolumn{2}{|c|}{$\begin{array}{c}\text { Availability of adequately iodized salt in the } \\
\text { household }\end{array}$} & \multirow[t]{2}{*}{$\operatorname{AOR}^{b}(95 \% \mathrm{CI})$} \\
\hline & Adequate, $n(\%)$ & Inadequate, $n(\%)$ & \\
\hline \multicolumn{4}{|l|}{ Knowledge about iodized salt } \\
\hline Poor knowledge & $114(53)$ & $102(47)$ & 1 \\
\hline Good knowledge & $57(32)$ & $121(68)$ & $1.88(1.18,3.01)^{*}$ \\
\hline \multicolumn{4}{|l|}{ Type of iodized salt } \\
\hline Unpacked $^{\mathrm{a}}$ & $114(53.3)$ & $100(46.7)$ & 1 \\
\hline Packed & $57(31.7)$ & $123(68.3)$ & $1.33(0.78,2.27)$ \\
\hline \multicolumn{4}{|c|}{ Type of container for iodized salt } \\
\hline Bag in which salt is bought & $29(29.9)$ & $68(70.1)$ & $1.16(0.53,2.55)$ \\
\hline Closed plastic & $90(45)$ & $110(55)$ & $1.07(0.6,1.9)$ \\
\hline Opened plastic & $52(53.6)$ & $45(46.4)$ & 1 \\
\hline \multicolumn{4}{|c|}{ Exposure of iodized salt to sunlight } \\
\hline Yes & $22(61.1)$ & $14(38.9)$ & 1 \\
\hline No & $149(41.6)$ & $209(58.4)$ & $2.35(1.1,5.2)^{*}$ \\
\hline \multicolumn{4}{|l|}{ Storage place of iodized salt } \\
\hline Dry place & $142(41.6)$ & $199(58.4)$ & $4.77(1.39,16.45)^{*}$ \\
\hline Cold place & $4(30.8)$ & $9(69.2)$ & $8.23(1.44,47.19)^{*}$ \\
\hline Next to fire & $10(47.6)$ & $11(52.4)$ & $2.95(0.65,13.45)$ \\
\hline Moist place & $15(78.2)$ & $4(21.1)$ & 1 \\
\hline
\end{tabular}

Notes. ${ }^{*}$ Statistically significant at $p<0.05$. ppm: parts per million. ${ }^{a}$ The salt is bought from the market without any package. ${ }^{\mathrm{b}}$ Adjusted for storage place, types of container, type of iodized salt, exposure to sunlight, income of householders, occupation of head of household, religion of head of household, and knowledge of household head about iodized salt.

Ethiopia. The overall proportion of households using adequately iodized salt ( $\geq 15$ parts per million) was found to be $56.6 \%$. This finding is far below the World Health Organization target $(\geq 90 \%)$ to eliminate iodine deficiency disorders [1]. The finding of this study reveals that the proportion of households with adequately iodized salt is lower than the study reports from South Wollo (68.8\%) [21], Asella town (62.9\%) [22], and Sidama Zone, Ethiopia (65\%) [23]. In contrast, the finding of this study was higher compared to the reported result from Dabat district, Northwest Ethiopia (33.2\%) [24], Jijiga town, Eastern Ethiopia (26.6\%) [25], Maychew, North Ethiopia (33\%) [26], Lalo Asabi district, West Ethiopia (8.7\%) [27], Gondar town (28.9\%) [28], and Shebe-Senbo district, Ethiopia (26.2\%) [29].

When we compare the coverage of adequately iodized salt in this study with coverage of other countries with similar socioeconomic setup, the current finding is lower than the coverage in India (60\%) [30], Ghana (75.6\%) [31], and South Africa (63\%) [32]. But, it is slightly higher than the reports from Sudan (14.4\%) [33] and Pakistan (15\%) [34]. This variation could be related to a difference in the time the studies were conducted. As evidence from the Ethiopian demographic and health survey, the coverage of iodized salt increased from $28.4 \%$ [12] in 2000 to $89 \%$ in 2016 [16]. Even if the national surveys show that coverage of iodized salt at the household level is increased over the years, adequacy of the iodine level in the salt is still very low [15]. Additionally, it might be due to differences in availability and accessibility of iodized salt in the market, policies to fortify salt with iodine, and monitoring regarding utilization of iodized salt in those countries.
This study found that householders who did not expose dietary salt to the sunlight were more likely to have adequately iodized salt $(\mathrm{AOR}=2.3595 \% \mathrm{CI}: 1.1-5.2)$ compared to their counterparts. This finding is supported by previous studies [21, 28, 35]. This might be due to the halogen nature of iodine, and its exposure to excess oxygen and carbon dioxide slowly oxidizes it to metal carbonate and elemental iodine which then evaporates [36].

This study also revealed that householders who store iodized salt at a dry or cold place were more likely to have adequately iodized salt compared to those who stored the iodized salt at moist places. This might be due to the volatility nature of iodine, and it needs optimum temperature and humidity to keep the iodine in the dietary salt stable [37].

A higher proportion of adequately iodized salt was observed among householders who had good knowledge about iodized salt and iodine deficiency disorders $(\mathrm{AOR}=1.8895 \% \mathrm{CI}: 1.18-3.01)$ compared to their counterparts. This finding is in line with the study done in Dabat district, North-west Ethiopia [24], Asella town, east Arsi zone [22], and Sidama zone, South Ethiopia [23]. It is plausible that individuals with better knowledge tend to demand and consume iodized salt than those without adequate knowledge [31, 38].

This study assessed the magnitude and factors associated with availability of adequately iodized salt at the household level. The findings of this study should be used in light of the following limitations: the study used the rapid test kit to determine availability of iodine in the salt, and other quantitative methods like titration were not used. Moreover, the study used a cross-sectional study design, so it does not guarantee a cause-effect relationship between factors and 
outcome variables. Furthermore, seasonal change in the availability and accessibility of adequately iodized salt might not be addressed by this study due to the nature of the study. Finally, this study will not warrant the intake of sufficient iodine since we did not assess the urinary iodine concentration of the sampled population.

\section{Conclusion}

The availability of adequately iodized salt in the study area was far below the World Health Organization recommendation. Not exposing dietary salt to sunlight, storing iodized salt at a dry and cold place, and having good knowledge about iodized salt were significantly associated with the presence of adequately iodized salt at the household level. Information regarding the importance of iodized salt and proper handling of dietary salt should be communicated to the householders.

\section{Data Availability}

The data that support the findings of this study are available from the corresponding author upon reasonable request.

\section{Conflicts of Interest}

The authors report no conflicts of interest in this work.

\section{Acknowledgments}

The authors would like to thank all respondents for their willingness to participate in the study.

\section{References}

[1] World Health Organization, ICCIDD. Assessment of Iodine Deficiency Disorders and Monitoring Their Elimination. A Guide for Programme Managers, World Health Organization, Geneva, Switzerland, 2007.

[2] A. Z. Win, "Micronutrient deficiencies in early childhood can lower a country's GDP: the Myanmar example," Nutrition, vol. 32, no. 1, pp. 138-140, 2016.

[3] P. Trerotoli, A. Ciampolillo, G. Marinelli, R. Giorgino, and G. Serio, "Prevalence of thyroid nodules in an occupationally radiation exposed group: a cross sectional study in an area with mild iodine deficiency," BMC Public Health, vol. 5, no. 1, p. 73, 2005.

[4] M. B. Zimmermann and K. Boelaert, "Iodine deficiency and thyroid disorders," The Lancet Diabetes and Endocrinology, vol. 3, no. 4, pp. 286-295, 2015.

[5] B. De Benoist, E. McLean, M. Andersson, and L. Rogers, "Iodine deficiency in 2007: global progress since 2003," Food and Nutrition Bulletin, vol. 29, no. 3, pp. 195-202, 2008.

[6] M. Andersson, B. De Benoist, and L. Rogers, "Epidemiology of iodine deficiency: salt iodisation and iodine status," Best Practice \& Research Clinical Endocrinology and Metabolism, vol. 24, no. 1, pp. 1-11, 2010.

[7] UNICEF Nutrition Section, UNICEF. Division of Communications. Sustainable Elimination of Iodine Deficiency: Progress since the 1990 World Summit for Children, UNICEF, NY, USA, 2008.
[8] A. Adish, T. Chuko, A. Abay, V. Assey, and T. Desta, "Ethiopia: breaking through with a new iodized salt law," IDD Newsletter, vol. 41, no. 4, pp. 1-24, 2013.

[9] World Health Organization, Vitamin and Mineral Requirements in Human Nutrition, World Health Organization, Geneva, Switzerland, 2004.

[10] W. H. Secretariat, M. Andersson, B. De Benoist, F. Delange, and J. Zupan, "Prevention and control of iodine deficiency in pregnant and lactating women and in children less than 2years-old: conclusions and recommendations of the technical consultation," Public Health Nutrition, vol. 10, no. 12A, pp. 1606-1611, 2007.

[11] M. Andersson, V. Karumbunathan, and M. B. Zimmermann, "Global iodine status in 2011 and trends over the past decade," The Journal of Nutrition, vol. 142, no. 4, pp. 744-750, 2012.

[12] Central Statistics Authority, Ethiopia Demographic and Health Survey 2000, Central Statistics Authority, Addis Ababa, South Ethopia, 2001.

[13] Central Statistics Authority, Ethiopia. YaMā'ekalāwi Stātistiks Bālaśeltāan, ORC Macro. Ethiopia Demographic and Health Survey, 2005, Central Statistical Authority, Addis Ababa, South Ethopia, 2006.

[14] Central Statistical Agency and ICF International, Demographic E. Health Survey 2011 Addis Ababa. Ethiopia and Calverton, Central Statistical Agency and ICF International, MA, USA, 2012.

[15] D. Zerfu, "National salt iodization coverage toward prevention of iodine deficiency disorder in Ethiopia," Ethiopian Public Health Institute, Addis Ababa, South Ethopia, 2014.

[16] E. Edhs, "Demographic and health survey 2016: key indicators report," The DHS Program ICF, vol. 363, p. 364, 2016.

[17] L. Takele, T. Belachew, and T. Bekele, "Iodine concentration in salt at household and retail shop levels in Shebe town, south west Ethiopia," East African Medical Journal, vol. 80, no. 10, pp. 532-539, 2003.

[18] D. Shawel, S. Hagos, C. K. Lachat, M. E. Kimanya, and P. Kolsteren, "Post-production losses in iodine concentration of salt hamper the control of iodine deficiency disorders: a case study in northern Ethiopia," Journal of Health, Population and Nutrition, vol. 28, no. 3, pp. 238-244, 2010.

[19] K. Girma, E. Nibret, and M. Gedefaw, "The status of iodine nutrition and iodine deficiency disorders among school children in Metekel Zone, northwest Ethiopia," Ethiopian Journal of Health Sciences, vol. 24, no. 2, pp. 109-116, 2014.

[20] W. P. Kumma, Y. Haji, J. Abdurahmen, and Y. Mehretie Adinew, "Factors affecting the presence of adequately iodized salt at home in wolaita, southern Ethiopia: community based study," International Journal of Food Sciences and Nutrition, vol. 2018, Article ID 4394908, 9 pages, 2018.

[21] T. C. Mekonnen, S. Eshete, Y. Wasihun, M. Arefaynie, and N. Cherie, "Availability of adequately iodized salt at household level in dessie and combolcha towns, South Wollo, Ethiopia," BMC Public Health, vol. 18, no. 1, p. 1152, 2018.

[22] S. Hawas, S. Lemma, S. Mengesha, H. Demissie, and M. Segni, "Proper utilization of adequatly iodized salt at house hold level and associated factores in Asella Town Arsi Zone Ethiopia: a community based cross sectional study," Journal of Food Processing and Technology, vol. 7, no. 4, p. 573, 2016.

[23] M. Tsegaye, D. Hailu, and M. Zegeye, "Availability and utilization of adequately iodized salt by urban and rural households and associated factors in southern Ethiopia, Sidama Zone, Bensa Woreda: a comparative cross-sectional study," International Journal of Food Sciences and Nutrition, vol. 6, no. 3, pp. 62-71, 2016. 
[24] Z. Abebe, A. Tariku, and E. Gebeye, "Availability of adequately iodized in Northwest Ethiopia: a cross-sectional study," Archives of Public Health, vol. 75, no. 1, p. 33, 2017.

[25] A. Tahir, B. Seyoum, and H. Kadir, "Use of iodized salt at household level in jig jiga town, eastern Ethiopia," Asian Journal of Agriculture and Life Sciences, vol. 1, no. 2, pp. 18-24, 2016.

[26] B. Gidey, K. Alemu, A. Atnafu, M. Kifle, Y. Tefera, and H. Sharma, "Availability of adequate iodized salt at household level and associated factors in rural communities in Laelay Maychew District, Northern Ethiopia: a cross sectional study," Journal of Nutrition and Health, vol. 2, no. 1, p. 1, 2015.

[27] D. Meselech Regassa, H. Tsedeke Wolde, and J. Befirdu Mulatu, "Utilization of adequately iodized salt on prevention of iodine deficiency disorders at household level and associated factors in Lalo Assabi District, West Ethiopia," Journal of Nutritionande Food Sciences, vol. 6, no. 471, p. 2, 2016.

[28] H. G. Gebremariam, M. E. Yesuf, and D. N. Koye, "Availability of adequately iodized salt at household level and associated factors in Gondar town, Northwest Ethiopia," ISRN Public Health, vol. 2013, Article ID 160582, 6 pages, 2013.

[29] Y. Mezgebu, A. Mossie, P. Rajesh, and G. Beyene, "Prevalence and severity of iodine deficiency disorder among children 612 years of age in shebe senbo district, jimma zone, southwest Ethiopia," Ethiopian Journal of Health Sciences, vol. 22, no. 3, pp. 196-204, 2012.

[30] B. K. Patro, P. Saboth, S. Zodpey, A. Shukla, M. G. Karmarkar, and C. S. Pandav, "Tracking progress toward elimination of iodine deficiency disorders in Jharkhand, India," Indian Journal of Community Medicine: Official Publication of Indian Association of Preventive and Social Medicine, vol. 33, no. 3, p. 182, 2008.

[31] C. Buxton and B. Baguune, "Knowledge and practices of people in Bia District, Ghana, with regard to iodine deficiency disorders and intake of iodized salt," Archives of Public Health, vol. 70, no. 1, p. 5, 2012.

[32] P. L. Jooste, M. J. Weight, and C. J. Lombard, "Iodine concentration in household salt in South Africa," Bulletin of the World Health Organization, vol. 79, no. 6, pp. 534-540, 2001.

[33] M. S. Mahfouz, A. M. Gaffar, and I. A. Bani, "Iodized salt consumption in Sudan: present status and future directions," Journal of Health, Population, and Nutrition, vol. 30, no. 4, p. 431, 2012.

[34] G. N. Khan, I. Hussain, S. B. Soofi, A. Rizvi, and Z. A. Bhutta, "A study on the household use of iodised salt in Sindh and Punjab provinces, Pakistan: implications for policy makers," Journal of Pharmacy and Nutrition Sciences, vol. 2, no. 2, pp. 148-154, 2012.

[35] R. Roy, M. Chaturvedi, D. Agrawal, and H. Ali, "Household use of iodized salt in rural area," Journal of Family Medicine and Primary Care, vol. 5, no. 1, pp. 77-81, 2016.

[36] K. Waszkowiak and K. Szymandera-Buszka, "Effect of storage conditions on potassium iodide stability in iodised table salt and collagen preparations," International Journal of Food Science and Technology, vol. 43, no. 5, pp. 895-899, 2008.

[37] G. Y. Wang, R. H. Zhou, Z. Wang, L. Shi, and M. Sun, "Effects of storage and cooking on the iodine content in iodized salt and study on monitoring iodine content in iodized salt," Biomedical and Environmental Sciences: BES, vol. 12, no. 1, pp. 1-9, 1999.

[38] B. Strange, M. Joseph, S. Kaushik, S. Dey, S. Dutt, and R. Jha, "Reaching the rural poor in India with iodized salt: the micronutrient initiative's iodized salt coverage study 2010," IDD News Letter, vol. 39, pp. 6-8, 2011. 